\title{
AXIOLOGICAL ANALYSIS ON NETFLIX SERIES "SQUID GAME" AS AN EFFORT TO INCREASE AWARENESS OF SOCIAL ISSUES AMONG GENERATION Z
}

\author{
${ }^{1}$ Bakdiyatul Mukarromah, ${ }^{2}$ Jihan Aqil Rihhadatul 'Aisy, ${ }^{3}$ Moses Glorino Rumambo Pandin \\ ${ }^{1,2,3}$ Faculty of Humanities, Universitas Airlangga \\ 1 bakdiyatul.mukarromah-2020@fib.unair.ac.id, ${ }^{2}$ jihan.aqil.rihhadatul-2020@ fib.unair.ac.id, \\ 3.moses.glorino@fib.unair.ac.id
}

\begin{abstract}
The internet is one of the impacts of new technology development, which can be used to find out the culture that exists in certain regional areas. The swift enlargement of information and communication technology has affected the public culture, both in the form of positive and negative impacts. Improvements and technological advances offered in this era make it easier for the community to access many things, one of which is entertainment media such as Netflix. Netflix's new series entitled "Squid Game" is being watched by millions of people around the world because of its unique storyline; it tells the story of a group of adults who are deeply in debt, who struggle to get a prize worth billions of Won (the official currency of South Korea) with their lives at stake. Unfortunately, the young generation nowadays is only a drama connoisseur who just follows trends, without exploring the messages and values contained in them. Therefore, the author analyzes the Netflix series "Squid Game" using an axiological approach as an effort to increase awareness of social issues among generation $\mathrm{Z}$. This study uses a qualitative method with google form as an observation instrument and relevant literature sources. Academically, this research is hoped to contribute to science development which is related to the philosophy of science, and axiology in particular. Practically, it is hoped that it can be useful for readers, especially as a stimulant in the practice of axiological thinking in everyday life. This research shows that Generation $\mathrm{Z}$ at first was not aware of the social issues contained in the Squid Game. However, after getting a little stimulant, they can identify social issues that occur in the Squid Game, compare them with social issues in Indonesia, and consider Squid Game as a way to increase awareness of Generation $\mathrm{Z}$ on social issues.
\end{abstract}

Keywords: Axiology, Squid Game, Social issue, Generation Z, Series, Drama

\section{INTRODUCTION}

The use of Information and Communication Technology (ICT) in Indonesia shows a significant development from year to year. The Central Bureau of Statistics of Indonesia (2019) stated that the percentage of the population using cellular phones in 2019 reached 63.53 percent. In addition, household ownership of computers and internet access has also grown to reach $18.78 \%$ for computers and $73.75 \%$ for internet access holding (BPS, 2019). Internet implementation has also risen with an achievement of 47.69 percent in 2019 (BPS, 2019). Improvements and technological advances offered in this era make it easier for the public to access many things, one of which is entertainment media such as Netflix.

Netflix is a digital streaming service provider based on members subscription that grants its users to watch TV series, movies, etc. without ads through internet-connected 
devices (help.netflix.com, undated). Netflix itself is the largest entertainment platform in the world, as evidenced by its total subscribers reaching 203.7 million people from its initial operation until 2020. (databoks.katadata.co.id, 2021). Inside, there are various viewing options, both in the form of films or drama series from within and outside the country with different genres.

Currently, the new Netflix series entitled "Squid Game" is being watched by millions of people around the world. Squid Game is a Korean thriller drama series with a total of 9 episodes. (netflix.com, 2021). This drama series is unique because it tells the story of a group of adults who are in debt. They fought to win this event to take home the prize of tens of billions of Won (the official currency of South Korea) which is equivalent to hundreds of billions of rupiah. The state is that players must complete missions in the form of children's games that have been compiled by the organizers who are described as mysterious figures in the story.

In addition, with the implementation of the work and school from home policies during the current pandemic caused by coronavirus and its variations, the number of access to social media has increased drastically. This also makes this drama even more boisterous, apart from the fact that many influencers share footage or simply show that they have watched Squid Game. One of the parts that was highlighted by the audience was the dalgona candy game as evidenced by the appearance of many tutorials for making these sweets on Instagram, TikTok, and even news pages both offline and online, such as Kompas.com (2021).

Seeing this, it is very unfortunate that today's young generation are only drama passive goers, just following the existing trends without exploring the messages and values contained in them. Especially for Generation Z, those who were born between 1997 to 2012, as the most active internet users in the world nowadays (Kim and Igielnik, 2020). Therefore, the author wants to analyze the Netflix series "Squid Game" using an axiological approach, as an effort to increase public awareness of ethical values and socio-political life in this digital stage.

This paper intends to identify the values contained in the drama series "Squid Game" viewed from an axiological perspective and reflect the values contained in the drama series "Squid Game" in everyday life. Academically, this research is anticipated to contribute to science development which is related to the philosophy of science, and axiology in particular.. Practically, it is hoped that it can be useful for readers, especially as a stimulant in the practice of axiological thinking in everyday life.

\section{METHODS}

This research includes empirical research using a qualitative approach because the problems that arise relate to humans which are fundamentally dependent on observations. Moleong $(2011,6)$ declared that qualitative study is study that intends to recognize phenomena about research subjects' social involvement, such as habit, perceptions, motivations, and others holistically, and employing descriptions in the form of words and language, in a special natural context and by utilizing various natural methods. Based on this understanding, it can be concluded that a qualitative approach is an approach that is carried out with a deep focus, using analysis where the results of the approach are then described in descriptive form. In this approach, meaning is emphasized more than generalization. 
This study uses two main data sources, which are secondary and primary data. Secondary data is details that are not taken straightly by the researcher but obtained from other sources that have been processed. Thus, the researcher becomes the second hand in the data processing. This was done because of the limitations of researchers in collecting data on a macro scale. Meanwhile, primary data was obtained by involving the active participation of researchers to obtain field data. The data requirements for this research include: (i) further studies on axiological values; (ii) the viewer's opinion on the Korean Drama series "Squid Game".

The strategy used to obtain secondary data is to access it via the internet. Meanwhile, primary data can be obtained through the creation of a google form containing open-ended questions to find out the response from the drama audience. Because it is a series with an age limit of 18 years and over, the informants of generation $\mathrm{Z}$ we get are in the age range of 18 to 25 years, which generally also comes from college students. Furthermore, the data will be processed using a qualitative method with an axiological approach.

\section{RESULTS AND FINDINGS}

\section{General plot and opinion about Squid Game}

In general, Squid Game tells the story of various children's games in South Korea that are packaged into a game between life and death by an old man who wants to spend his wealth at the end of his life. Although the reason behind the creation of the game is quite trivial, the system used is very complicated starting from determining and utilizing location, optimizing space, utilizing technology, and security systems. In addition, the prizes offered are very large, reaching tens of billions of won which is equivalent to hundreds of billions of rupiah. On the other hand, the targets offered by the game implementers to become participants in this game are from lower economic class communities who do have something to pay with large amounts of money, which seems impossible for them to get other than by participating in this game.

Initially, they did not get a detailed explanation of what they would do in the Squid Game. They were simply told that by winning the game, they could take home a very valuable prize, which was sufficient to cover their subsistence and other immediate needs. However, after knowing the real reality of the Squid Game, many participants want to stop in the middle of the game, and this is allowed on condition that they get $50 \%+1$ approval from the total game participants. Unfortunately, after they returned to their normal lives, some of them felt that being in the Squid Game was better than their own normal life, because of how miserable their lives were. Thus, the participants who were already involved in the game began to force themselves to continue following the game, in the hope of becoming the only winner and the only participant who survived and received the prize money to fight the financial "catastrophe" they experienced.

Based on the google form that we distributed among the viewers of the Squid Game series, many viewers were surprised by the story presented by Squid Game. In general, the storyline is very unique, exciting, and has never appeared before in similar Korean Dramas. Like the participants in the game, the audience did not expect 
that a children's game which should be a nostalgic thing that is fun to do and remember, becomes a traumatic thing to go through. Some viewers of this drama also feel that there are plot twists in the story, such as (i) the main organizer and drafter of this game is one of the players with serial number 001, who is none other than the old man, and (ii) the older brother of the police investigating This case is the leader of the Squid Game surveillance and security team. However, some argue that the plot twists in this story are not very prominent and can still be guessed, and indeed the storyline, concepts, and visuals that are displayed are the most memorable. Specifically, some viewers were touched by the story behind the participation of the Squid Game players, which incidentally started from financial problems.

On the other hand, some viewers feel that the Squid Game storyline is only interesting at the beginning. In the middle of the story, the plot is slow and uninteresting, considering that this drama series consists of several episodes and is quite long for each episode. Because, the audience can predict what will be shown in the next episode; Another survival game that eliminates -kills, to be exact- some of the game's participants. Its consistent flow is a good point, but it can also be boring repetition.

In addition, apart from the external appearance of the Squid Game series such as storyline, visualization, and character development, many viewers feel that this series is quite good in terms of the messages contained in it, which the team is trying to convey to the audience either directly or indirectly. indirect. This will be discussed further in the next section.

\section{The influence of social media}

Instagram is an image-based social media that provides online photo or video sharing services (facebook.com, n.d.). Instagram comes from the understanding of the overall function of this application. Instagram allows users to send and get information quickly using the Internet network. Also, there is TikTok as an application for making and sharing short videos up to 3 minutes long. The videos are portrait, not horizontal or square like on YouTube or Instagram feed, and you navigate through them by scrolling up and down, not by tapping or swiping side to side (Herrman, John, 2019). Another social media that is often used is Twitter. Help.twitter.com (no date) defines Twitter as an app for the public to communicate and stay connected through messages called tweets with a maximum of 280 characters per tweet. Twitter is more focused on writings, not visual beauty as a form of expression.

The online survey conducted shows the connection between social media and generation $\mathrm{Z}$ on their daily activity, especially decisions on movies to watch. $54,2 \%$ of respondents said they knew about Squid Game through TikTok, 50\% of respondents said knew this series was viral from Instagram, 33,3\% of respondents knew this series through thread shared on Twitter and the last have mixed answers; got the suggestion from friends, Netflix home screen, and got a recommendation from family. It shows how social media can blow up something from a usual series to a viral one.

\section{The most pointed out part in the Squid Game}


In this section, we want to find out which is the most highlighted part of the Squid Game series. Regardless of the type of game, the three things that most often emerge from the answers of the informants are the instinct of survival, social inequity, and poverty. Following after are murder, gender inequality, and discrimination between the strong and the weak.

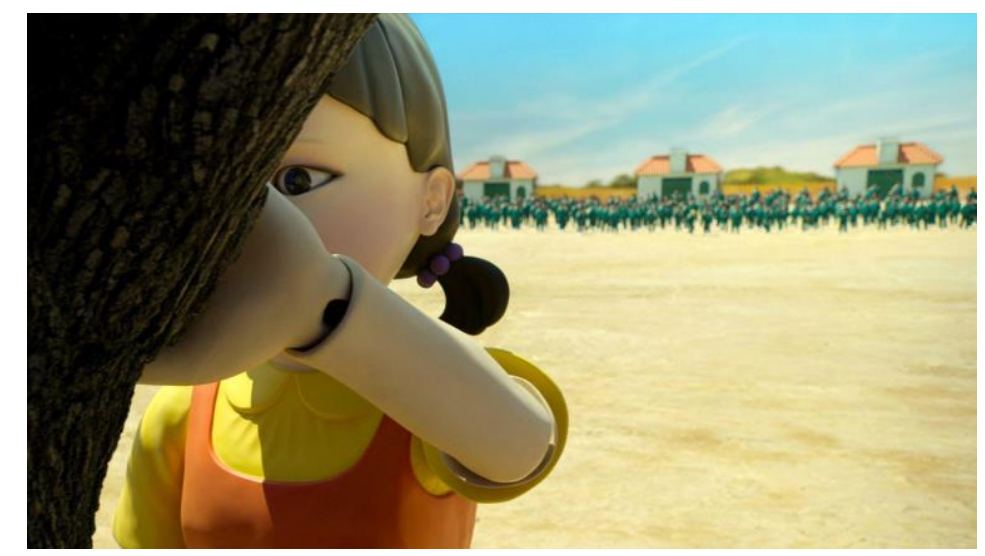

Figure 1. Red Light and Green Light Game

The first type of game that is highly highlighted is the "Red Light and Green Light" game, where there is one robot "tagger" and the other players must reach the tagger before the allotted time limit runs out. The main point is, when the tagger robots look at the player, they must not move an inch, or they will be shot dead on the spot. Because this game was the first to be played, all of the game participants suddenly felt panic and fear when they saw the punishment for the losing participants. After this game ended, they agreed to quit this game.

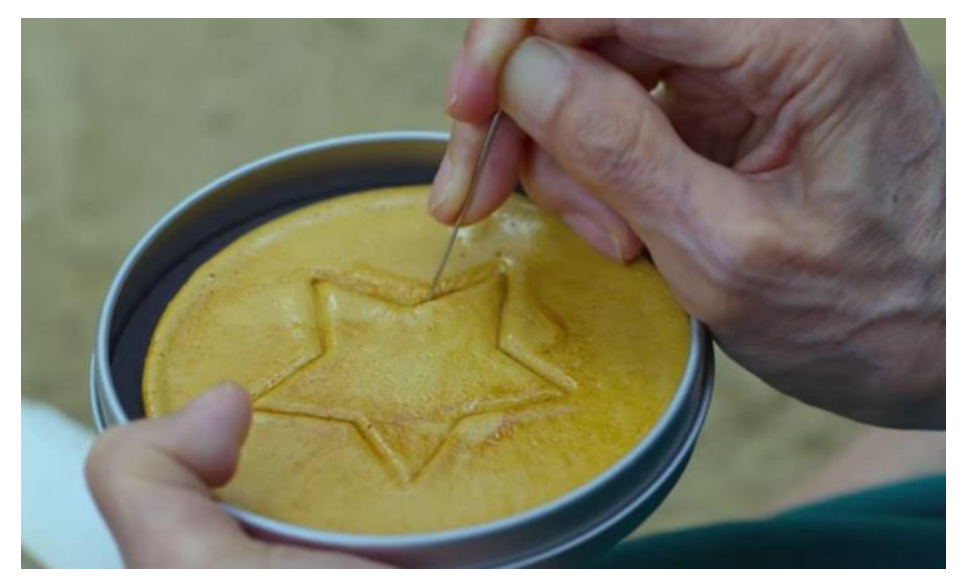

Figure 2. Dalgona Candy

The next highlighted game is making dalgona candy. In fact, this game is not focused on how to make dalgona candy itself but lies in the unique shape that they have to get. For example, as in figure 2, players must separate the star shape from the circle shape using only a needle in the allotted time. If they fail, they will be shot dead by the supervisors as well as the security officers there.

Next, is the survival instinct that every player has in the Squid Game. The series shows that when in a state between life and death, humans tend to be concerned with themselves rather than others. Thus, their competitive nature is so high that they are 
able to take the lives of others for their sake. Only a handful of people still have the remnants of humanity in them, which makes them still care about or help others in any situation.

Some viewers also highlight the social inequity and poverty that showed in this Netflix series. It presents a huge gap between the poor and the rich bluntly. When people from the lower economic circles try desperately to fulfill their needs, the bourgeoisie actually squanders its wealth on things that are not of value; only to seek worldly satisfaction and pleasure. Several scenes show that the bourgeoisie underestimates other human beings because they feel that anyone will submit to the money and rank they have. There is also a scene that shows that for the sake of money, anyone can do anything, whether they come from the poor or the rich though. Sadly, this often happens in the real world, not only in movies. The poverty reflected in this drama series is also inversely proportional to the South Korean side that has been reflected on the internet and other K-drama series. This reflects that the brighter a light appears, the shadows that follow will remain and even get darker.

Then, some people highlight the section on gender injustice. In one of the games, tug of war, players are invited to choose their team partner. Unfortunately, some characters cheat and know in advance the type of game to be played. So, when selecting teammates, they only choose men and those who are strong. One of the characters, who even has a "lover", is willing to throw the woman away and form his team. Finally, because of these cheats, many women and parents who do not know anything become easy targets in the game.

\section{Opinion about similar issues happening in Indonesia}

As described in the previous paragraphs, the Squid Game represents several social issues that occur in Indonesia, and may even occur in other countries. In this section, the author will describe several points based on the author's point of view and the audience as informants in this study.

a. Poverty and social inequality

Poverty is a long-standing issue in Indonesia, and it can be regarded as a multidimensional problem (Hamudy, 2008). Kurniawan (2004) defines poverty as something experienced by a group of people whose income is below a certain threshold. According to the Indonesian Central Statistics Agency, the number of indigent people in March 2021 is 10.14 percent of the total population, which when converted into numbers becomes 27.54 million people. This is inseparable from the role of the COVID-19 pandemic, which has also caused Indonesia to drop its ranking from a country with an uppermiddle-income predicate to a lower-middle-income country starting in July 2021 (worldbank.org, 2021).

In this situation, the gap between the rich and the poor is widening, as indicated by the large Gini ratio in Indonesia. The Gini Ratio or Gini Coefficient is a tool used to measure the degree of disproportion in the distribution of the population. It can also be a measure of imbalance or aggregate inequality (overall) between cumulative income and a cumulative population whose numbers range from zero (perfect equality) to one (perfect 
inequality) (berkas.dpr.go.id, n.d.). Based on BPS Indonesia itself, the level of inequity in spending by the Indonesian population, in general, is 0.384 in March 2021. If detailed, the Gini ratio in suburban areas reaches 0.401 and the Gini ratio in countryside areas is 0.315 (BPS, 2021).

b. Gender Inequality

This social issue is also rife in the community, not only in Indonesia but also in the world. Movements and awareness of gender equality began to be widely voiced, along with the rejection of feminism, masculinity, and patriarchy. Feminism and masculinity are correlated to each other. Hidayati (2018) defines feminism as an idea of broad-based research of social experience that originated from a women-centered perspective, while masculinity is a mindset in which a man should be an alpha and not depend on others (Jatnika and Hermawan, 2018). Besides, patriarchy is a system in which males have dominance and superiority over women (Rokhimah, 2015).

Because of the rise of this awareness, the public is starting to realize that many gender injustices occur around them. One of the most ingrained in Indonesia is the idea that women should not leave the house and work. Rohika Kurniadi Sari, Assistant Deputy for Fulfillment of Children's Rights to Care, Family, and Environment at the Ministry of Women's Empowerment and Protection, explained in a discussion welcoming International Women's Day which was held in Jakarta, Wednesday (5/3/2020) that the gap between women and men was still like homework that needs to be done. Starting from violence, child marriage, and high divorce rates. Often women are only seen as assets, weak, and have no rights over themselves.

\section{Squid Game as Reminder of Social Issues in Indonesia}

In this case, the informants were divided into two camps; those who agree and disagree with the discourse. Informants who agree, feel that many things can be obtained from this Netflix series from various points of view. For example, reminding the public that making money is not an easy matter. However, keep in mind that in order to get the money, we should not harm ourselves and even others. On the other hand, as human beings, we must increase our sense of humanity. Humans are required to be sensitive to the surrounding environment, and help those who are in trouble. If we are unable, we can provide moral support and encouragement to them and together accompany them so that they can solve their problems in the right way. Thus, social disparity and the crime rate can be minimized, considering that poverty is also the cause of various criminal cases in Indonesia such as theft, robbery, beheading, bullying, and so on. Gender equality can also be enforced so that women are not seen as weak and become a place for blame.

In contrast, informants who do not agree feel that this series is too extreme and unrealistic, and will not necessarily be well received among Indonesian inhabitants because of cultural differences and social conditions. It is also not fully known whether the Indonesian citizens have a good "filter" in taking something from a spectacle, considering that the public, in general, is more focused on viral things or only on drama players. The informants are also worried that the viewers will take 
what is written, such as justifying any means to get money, instead of taking what is implied, such as a bad way to get something that will end badly too. Furthermore, the Squid Game is feared to be an idea for individuals who are not wise enough to play with someone's life, because of the many murder scenes in this drama, and even the illegal trafficking of human organs. Some informants also said that this show is not suitable for viewing for a certain age, but according to the writer of the drama Squid Game, it has an appropriate age limit. It's just that some viewers may violate the age limit that has been set.

\section{DISCUSSION}

In the development of life, science is progressing. The development of this science can be realized because of activities in the form of research carried out by scientists. The ability to know is what makes humans have a higher value than other creatures. According to Soetriono and Rita Hanafie (2007) this ability lies in creativity because it is directly related to the Creator. This creativity is a beginner in all fields, reason, science, ethics, and aesthetics. Science, technology, and culture are required to contribute to solving concrete problems faced by the community, nation, and state in a critical, comprehensive, and evaluative way.

Each branch of science, technology, and culture needs to always pay attention to its philosophical foundations, namely the ontology, epistemology, and axiology foundations. According to Jujun S. Suriasumantri (1996), the term axiology is defined as a theory of value, relating to the usefulness of the knowledge gained. In theory, axiology is divided into three parts, namely: (1) Moral Conduct, (2) Esthetic Expression, and (3) Socio-Political Life. Etymologically, axiology comes from Ancient Greek, namely "aksios" which means value, and the word "logos" means theory. So, axiology is a branch of philosophy that studies values. In other words, axiology is a theory of value.

Axiology is a field that investigates values. The values and implications of axiology examine and integrate all values (the value of moral action, the value of expression of beauty, and the value of socio-political life) in human life and instill them into the child's personality. The question related to axiology is what is good or good? (Muhammad Noor Syam, 1986 in Jalaluddin, 2007: 84).

The points that will be discussed a lot in this paper cover the three points that have been mentioned, although they will be heavy in the first and third points because they are very related to social issues. Rubington and Weinberg (1989) state that a social problem is a condition that is stated to be inconsistent with the values held by some citizens, who agree that a joint activity is needed to change that condition. The values that can be taken from this research are as follows.

1. Humanity, shown by how we should be able to respect others regardless of social status. Each individual is expected to have an awareness of attitudes and behavior that are in accordance with moral values in living together on the basis of the demands of their respective consciences, by treating things properly. Humans develop science and technology while holding on to the basics of morality to achieve common prosperity.

2. Social justice, shown by how we should be able to create a balance in the relationship between each other. Creating equal opportunities for all people. There 
is a system that is able to regulate the balance. Where every human being, the lower middle class, the upper-middle class, men, and women should not be discriminated against in education, economics, and even political policy.

\section{CONCLUSION}

A problem is an event or symptom that will never be separated from human life because human life is a process of struggle to overcome problems. Overall, the Squid Game implies many things that we can use as reminders where in fact there are many problems that we must face in implementing state practice, ranging from issues of poverty, social inequity, to gender inequality. From an axiological perspective, the analysis of the Squid Game series is more focused on ethical issues or human moral values. The relationship between ethical problems is seen because there are behavioral deviations that occur in the midst of society. In the future, it is hoped that Generation $\mathrm{Z}$ will realize that many social issues are implied in a film or certain entertainment media that we should be able to use as a reminder to stick to the values of humanity and social justice in everyday life.

\section{REFERENCES}

Affandi, Abdullah dan Muhammad Firza Alaydrus. (2019). Fungsi Filsafat Ilmu Dalam Pengembangan Metode Ilmiah. Al-Hikmah: Jurnal Kependidikan dan Syariah 7(1), 80-85. http://www.jurnal.staiba.ac.id/index.php/Al-Hikmah/article/view/91

Badan Pusat Statistik: Subdirektorat Statistik Komunikasi dan Teknologi Informasi. (2019). Statistik Telekomunikasi Indonesia 2019. Badan Pusat Statistik. Jakarta

Badan Pusat Statistik. (2021). Persentase Penduduk Miskin Maret 2021 turun menjadi $10,14 \quad$ persen. bps.go.id https://www.bps.go.id/pressrelease/2021/07/15/1843/persentase-penduduk-miskinmaret-2021-turun-menjadi-10-14-persen.html

Badan Pusat Statistik. (2021). Gini Ratio Maret 2021 tercatat sebesar 0,384. bps.go.id https://www.bps.go.id/pressrelease/2021/07/15/1845/gini-ratio-maret-2021-tercatatsebesar-0-384-.html

$\begin{array}{lllll}\text { Berkas.dpr.go.id. } & \text { (tanpa } & \text { tahun). } & \text { Gini }\end{array}$ https://berkas.dpr.go.id/puskajianggaran/kamus/file/kamus-17.pdf

Databoks.katadata.co.id. (2021). Efek Pandemi, Total Pelanggan Netflix Tembus 200 Juta https://databoks.katadata.co.id/datapublish/2021/01/22/efek-pandemi-total-pelanggannetflix-tembus-200-juta

Facebook.com. no date. What is Instagram? www.facebook.com/help/instagram/424737657584573/?helpref=uf_share

Firdaus, Zumrotin, Tri Susilowati, Markhamah. (2020). Nilai Aksiologis Kebijakan Covid19. Didaktis: Jurnal Pendidikan dan Ilmu Pengetahuan 20(3)

Hamudy, M. I. A. (2008). Pengentasan Rakyat Miskin dan Pembangunan Manusia di Jawa Barat. Bandung: PPS FISIP UNPAD.

Help.netflix.com. (tanpa tahun). Apa itu Netflix? https://help.netflix.com/id/node/412

Help.twitter.com. (no date). New user FAQ. https://help.twitter.com/en/resources/new-userfaq 
Herrman, John. (2019). How TikTok Is Rewriting the World https://www.nytimes.com/2019/03/10/style/what-is-tik-tok.html

Hidayati, Nuril. (2018). Teori Feminisme: Sejarah, Perkembangan Dan Relevansinya Dengan Kajian Keislaman Kontemporer. Jurnal Harkat: Media Komunikasi Gender, 14(1). https://doi.org/10.15408/harkat.v14i1.10403

Jatnika, A. W., \& Hermawan, F. F. (2018). Menjadi Lelaki Sejati: Maskulinitas Dalam Komik Daring Webtoon Indonesia. Mudra Jurnal Seni Budaya, 33(1), 60-66. https://doi.org/10.31091/mudra.v33i1.158

Jirzanah. (2020). Aksiologi Sebagai Dasar Pembinaan Kepribadian Bangsa dan Negara Indonesia. UGM Press.

Kim, Jae-Ha. (2021). "Squid Game" Is a Social Allegory Informed by Korean History https://www.teenvogue.com/story/squid-game-social-allegory-informed-by-koreanhistory

Kim, Parker and Ruth Igielnik. (2020). On the Cusp of Adulthood and Facing an Uncertain Future: What We Know About Gen Z So Far. https://www.pewresearch.org/socialtrends/2020/05/14/on-the-cusp-of-adulthood-and-facing-an-uncertain-future-what-weknow-about-gen-z-so-far-2/

Kurniawan R.C. (2004). Poverty Pathology “An Ironic of A Country. Lampung: Department of Governmental Science - Faculty of Social and Politics Sciences, UNILA.

Kompas.com. (2021). Cara Membuat Permen Dalgona Seperti Permainan di Squid Game https://www.kompas.com/tren/read/2021/09/26/170500465/cara-membuat-permendalgona-seperti-permainan-di-drakor-squid-game

Kompas.com. (2021). Daftar 10 Aplikasi Mobile Teratas Di Awal 2021. https://tekno.kompas.com/read/2021/04/07/07240027/daftar-10-aplikasi-mobileteratas-di-awal-2021?page $=$ all

Moleong, L J. (2011). Metodologi Penelitian Kualitatif Edisi Revisi. PT. Remaja Rosdakarya. Netflix.com. (2021). Netflix Series: Squid Game. https://www.netflix.com/sg/title/81040344

Rokhimah, S. (2015). PATRIARKHISME DAN KETIDAKADILAN GENDER. MUWAZAH: Jurnal Kajian Gender, 6(1). Retrieved from http://ejournal.iainpekalongan.ac.id/index.php/Muwazah/article/view/440

Sidratul Munti, N. Y. ., \& Syaifuddin, D. A. . (2020). Analisa Dampak Perkembangan Teknologi Informasi Dan Komunikasi Dalam Bidang Pendidikan. Jurnal Pendidikan Tambusai, 4(2), 1975-1805. Retrieved from https://jptam.org/index.php/jptam/article/view/655

Suriasumantri, Jujun S. (1996). Filsafat Ilmu Sebuah Pengantar Populer. Pustaka Sinar Harapan dalam Rahmadani, Suci. (2018). Aksiologi dalam Pendidikan. Researchgate.net https://www.researchgate.net/publication/329988025_Aksiologi_dalam_Pendidikan

Tangdilintin, Paulus dan Bambang Prasetyo. Mengenal Masalah Sosial - Modul 1. Retrieved from Mengenal Masalah Sosial - PDF Free Download (adoc.pub)

Usman, Mariya. (2021). Patut Dicoba, Ini Resep Mudah Membuat Permen Dalgona Ala Squid Game. https://mediamagelang.pikiran-rakyat.com/entertainment/pr1432855946/patut-dicoba-ini-resep-mudah-membuat-permen-dalgona-ala-squid-game 
Voaindonesia.com (2020). Ketidaksetaraan Gender Masih Tinggi di Indonesia https://www.voaindonesia.com/a/ketidaksetaraan-gender-masih-tinggi-di-indonesia/5316082.html

Widhistia Putri, Adinda. (2018). "Penggunaan Instagram Stories Sebagai Personal Branding”. Fakultas Sosial dan Ilmu Politik. Program Studi Ilmu Komunikasi. Skripsi. Malang: Universitas Muhammadiyah Malang. http://eprints.umm.ac.id/43019/5/BAB\%204.pdf

Worldbank.org. (2021). Bank Dunia di Indonesia.
https://www.worldbank.org/in/country/indonesia/overview\#1 